\author{
Paolo Palumbo \\ (professore straordinario di Diritto ecclesiastico e canonico nell'Università \\ Telematica Giustino Fortunato di Benevento)
}

\title{
Digital religious celebrations during and after the Covid-19. Limits and opportunities for regulation *
}

\begin{abstract}
During the first phases of the pandemic until today, many religious activities, especially liturgical celebrations, have been suspended and reorganised. Drastic measures and choices were necessary, always in balance with constitutional principles. In this social and historical context, digital platforms seem to have turned into liturgical spaces. The contribution aims to highlight the problems and opportunities that have arisen and to present the practices used within confessional systems, particularly the Catholic one. Also in relation to a research on the subject, promoted by the Giustino Fortunato University, reflections are offered that may favour a better relationship between the needs of worship and liturgical and confessional law in the field of sacraments and celebrations.
\end{abstract}

SOMMARIO: 1. The pandemic and the damage occurred to the right of community religious freedom - 2. A survey on the exercise of the worship during lockdown - 3. Digital celebrations: is there a legal regulation?

\section{1 - The pandemic and the damage occurred to the right of community religious freedom}

It is undeniable that the pandemic, caused by the widespread outbreak of the Sars-CoV-2 virus, has overturned life on all levels for all humanity; in just a few days, the routine of all, their stance toward others, their ways to relate, have changed dramatically, with restrictive consequence on the exercise of the most "normal" daily actions, which were forbidden or limited. The lockdown, in Italy (starting from March 2020) has imposed strict measures, especially in relation to the compression and to the limitation of constitutionally relevant essential rights and freedom types ${ }^{1}$, one of them being the right to religious

\footnotetext{
* Il contributo riproduce, con aggiornamenti e apparato bibliografico, il testo della relazione presentata in occasione del Convegno Internazionale su "Tecnologia $e$
} 
freedom $^{2}$ - which is, by itself a not easily compressible right, being it a

Innovazione: nuovi modi per fare cose note?", organizzato dall'Università "Giustino Fortunato" di Benevento (15-16 dicembre 2020). Il testo è stato oggetto di valutazione positiva e approvazione da parte del Comitato Scientifico.

${ }^{1}$ Cf. S. PRISCO, F. ABBONDANTE, I diritti al tempo del coronavirus. Un dialogo, in Federalismi.it, 24 march 2020 (where the authors talk about "Costituzione sospesa"); V. PACILlO, La sospensione del diritto di libertà religiosa nel tempo della pandemia, in www.olir.it, 16 march 2020; M. CARRER, Salus Rei Publicae e salus animarum, ovvero sovranità della Chiesa e laicità dello Stato: gli artt. 7 e 19 Cost. ai tempi del coronavirus, in BioLaw Journal, n. 2, 2020, p. 1; F. ALICINO, Costituzione e religione in Italia al tempo della pandemia, in Stato, Chiese e pluralismo confessionale, Rivista telematica (https://www.statoechiese.it), 19, 2020, pp. 1-24.

${ }^{2}$ For a complete reconstruction of the measures taken and for a careful reflection on them, cf. F. BALSAMO, La leale collaborazione tra Stato confessioni religiose alla prova della pandemia da Covid-19. Una prospettiva dall'Italia, in Diritto e Religione nelle Società Multiculturali (www.diresom.it), 27 march 2020, pp. 1-8; F. BOTTA, Bagatelle per una pandemia, in Stato, Chiese e pluralismo confessionale, cit., 10, 2020, pp. 1-20; G.M. CAPORALE, L. TRAPASSI, La libertà di esercizio del culto cattolico in Italia in epoca di Covid-19. Una questione di diritto internazionale, in federalismi.it, Rivista di diritto pubblico italiano, comparato ed europeo (www.federalismi.it), 20 may 2020; N. COLAIANNI, La libertà di culto al tempo del coronavirus, in Stato, Chiese e pluralismo confessionale, cit., 7 , 2020, pp. 25-40; P. CONSORTI, Le religioni e il virus, in Diritto e Religione nelle Società Multiculturali (www.diresom.it), 9 march 2020, pp. 1-4; M. D'ARIENZO, Is the suspension of Catholic public Mass legitimate?, in Diritto e Religione nelle Società Multiculturali (www.diresom.it), 5 may 2020, pp. 1-2; ID., Emergenza coronavirus, autorità ecclesiastica e bene comune, in Il Regno, 10, 2020, pp. 262-263; G. FATTORI, La libertà religiosa al tempo del Coronavirus, in Diritto e Religione nelle Società Multiculturali (www.diresom.it), 6 april 2020, pp. 1-8; N. FIORITA, Libertà religiosa e solidarietà civile nei giorni della grande paura, in www.olir.it, 10 march 2020, pp. 1-2; A. FERRARI, Covid 19 e libertà religiosa, in www.settimananews.it, 6 april 2020, pp. 1-7; A. FUCCILLO, La religione "contagiata" dal virus? La libertà religiosa nella collaborazione Stato-Chiesa nell'emergenza covid- 19, in www.olir.it, 21 april 2020; A. LICASTRO, Il lockdown della libertà di culto pubblico al tempo della pandemia, in Consulta on line, 1, 2020, pp. 222-233; M.L. LO GIACCO, In Italia è in quarantena anche la libertà di culto, in Diritto e Religione nelle Società Multiculturali (www.diresom.it), 12 march 2020, pp. 1-8; G. MACRÌ, La libertà religiosa alla prova del Covid-19. Asimmetrie giuridiche nello "stato di emergenza" $e$ nuove opportunità pratiche di socialità, in Stato, Chiese e pluralismo confessionale, cit., 9, 2020, pp. 23-49; D. MILANI, Fede e salute al tempo del Coronavirus: un primo bilancio a un mese dal lockdown, in www.olir.it, 20 march 2020, pp. 1-3; ID., Covid-19 e libertà religiosa in Italia: lo spirito di resilienza dello Stato e della Chiesa davanti alla sfida della pandemia, in Ius Ecclesiae, 1, 2021, pp. 89-116; V. PACILLO, La sospensione del diritto di libertà religiosa nel tempo della pandemia, in www.olir.it, 16 march 2020, pp. 1-4; ID., Il diritto di ricevere $i$ sacramenti di fronte alla pandemia. Ovvero, l'emergenza da Covid- 19 e la struttura teologico-giuridica della relazione tra fedele e la rivelazione della Grazia, in www.olir.it, 6 april 2020, pp. 1-6; ID., La libertà di culto al tempo del coronavirus: una 
more ample type of freedom which sees the freedom of assembly, association, and thought expression as necessary additions ${ }^{3}$ that actualize behaviors and rituals strictly linked to the fact of being a community of observant people, with the consequence of having churches and places of worship not easily accessible, of being unable to participate in religious and ritual functions or to administer and access the sacraments and also of having funerals suspended ${ }^{4}$.

Such manifestations of the exercise of religious freedom have been "forbidden" 5 in view of the need to limit gatherings in order to guarantee public freedom, which derives from the more ample protection of the right to health for everyone. In this context of emergency change, a great quantity of government regulations meant to try and contain the spreading of the deceitful virus have been persistently and restrictively inserted, and have been reasonably criticized 6 . Following the pandemic's exceptional state of emergency declared by the World Health Organization, the extra ordinem interventions of the Government have been legitimized 7 . The State of

risposta alle critiche, in Stato, Chiese e pluralismo confessionale, cit., 8, 2020, pp. 85-94; ID., La libertà di culto al tempo del Covid-19, in La Rivista il Mulino, 10 april 2020, pp. 12; ID., La libertà di culto di fronte all'emergenza Covid-19. Profili di diritto canonico e di diritto ecclesiastico italiano, in Il Diritto Ecclesiastico, 1-2, 2019, pp. 11-34; R. SANTORO, G. FUSCO, Diritto canonico e rapporti Stato-Chiesa in tempo di pandemia, Editoriale scientifica, Neaples, 2020.

3 Cf. P. PALUMBO, Libertà religiosa e nuovi equilibri nelle relazioni tra Stato e confessioni religiose, in ID., Libertà religiosa e nuovi equilibri nelle relazioni tra Stato $e$ confessioni religiose, Editoriale scientifica, Neaples, 2019, pp. 7-27.

4 Cfr. P. PALUMBO, Funzioni funebri e "fase 2" dell'emergenza COVID-19. Brevi riflessioni sulle decisioni assunte dalle Diocesi in Italia, in Quaerere Deum, 19-20, 2020, pp. 185-200; ID., La fede al termoscanner. Riflessioni sull'avvio della fase 2 in ambito ecclesiale, in salvisjuribus.it, 14 may 2020.

5 Cfr. A. FUCCILlO, M. ABU SALEM, L. DECIMO, Fede interdetta? L'esercizio della libertà religiosa collettiva durante l'emergenza Covid-19: attualità e prospettive, in Calumet - Intercultural Law and Huminities Rewiew, Rivista telematica (www.calumetreview.it), 10, 2020, p. 93 ss.; A. FUCCILLO, La religione "contagiata" dal virus?, cit.

6 Cfr. M. CAVINO, Covid-19. Una prima lettura dei provvedimenti adottati dal Governo, in federalismi.it, Rivista di diritto pubblico italiano, comparato ed europeo (www.federalismi.it), 18 march 2020; M. LUCIANI, Il sistema delle fonti del diritto alla prova dell'emergenza, in Rivista AIC. Associazione Italiana dei Costituzionalisti, 2, 2020, pp. 109-141.

7 For a complete reconstruction of the measures taken and for a careful reflection on them, cf. R. SANTORO, G. FUSCO, Diritto canonico e rapporti Stato-Chiesa, cit., pp. 9-66. 
emergency has definitely demanded a quick response, and the imperative for high velocity, which has marked the phases of the emergency, has triggered, under a procedural and substantial profile, some "stretches" 8 for sure, but not an authoritative deviation of the system. The main perplexities have emerged from the indisputable fact that the fundamental rights of the citizens have been "compromised" by the provisions (DPCM), that, despite founded in primary force acts, on the basis of which the Prime Minister has been able to adopt special provisions to contrast the pandemic on the National territory, in their material impact consist of lesser acts in the sources system.

After the first phase of the pandemic and the heavy restrictions imposed by the Government, which were also applied to the religious community, the limitation in terms of attending Churches, Mosques, Synagogues and other places of worship has been interpreted by the law as a short circuit in the interorganizational dynamics and, particularly, in relation to the principle of pactional bilaterality that marks the constitutional system of the relations between State and religions ${ }^{9}$. Therefore, the measures adopted, by influencing the ritual activities of religious confessions, particularly those of the Catholic Church, that is, the center of the faith of the ecclesiastical community, (the essential community dimension of which has been overlooked), and that is founded on the ecclesiological character of the liturgy, have created, in the catholic frame work, a debate regarding the theological limitations of a sine populo Eucharistic celebration and, from a constitutional-legal point of view, in a more ample view, the doubt of an invasion of the order of competence of the religious confession, which is granted by the Constitution as intangible, being here ignored the bilateral obligation derived from the concordat agreements that solemnly recognize the Church itself (and other religious confessions, too), the freedom of public exercise of the worship.

The Catholic Church, in a view of responsibility and full cooperation with the civil authorities, has accepted the suspension of

8 Cfr. G. SILVESTRI, Covid-19 e Costituzione, in www.unicost.eu, 10 april 2020; N. COLAIANNI, La libertà di culto al tempo del coronavirus, cit.; G. AZZARITI, I limiti costituzionali della situazione d'emergenza provocata dal Covid-19, in Questione giustizia.it, 27 march 2020; L.A. MAZZAROLLI, Riserva di legge e principio di legalità in tempo di emergenza nazionale, in Federalismi.it, 23 march 2020.

${ }^{9}$ Cf. M. d'ARIENZO, Emergenza coronavirus, autorità ecclesiastica, cit., pp. 262-263; ID., Is the suspension of Catholic public Mass legitimate?, cit., pp. 1-2; G. BONI, Il fondamentale diritto dei fedeli ai sacramenti, in www.centrostudilivatino.it, 7 may 2020. 
religious celebrations, including funerals ${ }^{10}$ and has introduced control measures meant to avoid the participation of the worshippers to religious celebrations and functions. Following the declarations of the Italian Bishops regarding the fact that the «la Chiesa italiana soffre ma $\mathrm{fa}$ la sua parte per la tutela della salute pubblica»11 and without hiding the awareness of "un passaggio fortemente restrittivo, la cui accoglienza incontra sofferenze e difficoltà nei Pastori, nei sacerdoti e nei fedeli"12, the Italian Episcopal Conference has absorbed the application provisions of the control measures provided for by the government. In general, churches have remained open to the private worship and priests have continued their liturgical celebrations on their own or with other presbyters. Many parish realities have equipped themselves straight away in order to grant the distance "participation" of the worshippers to the celebrations through streaming systems launched by many social media or online platforms. The modalities regarding the participation of the worshippers to the Easter ceremony and to the celebration of weddings (but not to any other sacrament such as baptisms, confirmations, penance and sacred ordinations) have been clarified by the Ministry of Foreign Affairs, with a Note dated 28 March 202013, which specified that the access to churches (which; therefore, remained open) could happen in the closest place of worship and only on occasion of certain transfers to be proved by work needs, that is, by situations of need.

The church (intended as place of worship) has, therefore, always remained open during the lockdown, in order to welcome the worshippers that wanted to pray in a personal manner, and the restrictions have remained in place until encouraging epidemiological data were declared which stated a regression of the viral infection. The lockdown of celebrations, as stated above, has favored the employment of the new technological means, for the Eucharistic

10 Cf. P. CONSORTI, La libertà religiosa travolta dall'emergenza, cit., p. 2; ID., Le religioni e il virus, cit., pp. 1-4.

11 ITALIAN EPISCOPAL CONFERENCE, Comunicato stampa, n. 11, 2020, in www.chiesacattolica.it.

12 ITALIAN EPISCOPAL CONFERENCE, Nota, 5 march 2020; Lettera, 12 march 2020, in www.chiesacattolica.it.

13 Cfr. Nota of the Central Directorate for Worship Affairs, addressed to Monsignor Maffeis, Undersecretary of the Italian Bishops' Conference, 28 march 2020, in www.chiesacattolica.it. 
celebrations and other religious functions ${ }^{14}$, realizing and concretizing a new reality, never experienced before, offering the solution of the connection in streaming, which had puzzled both single worshippers and members of the church community, and that had raised many questions, and still does, in relation to the topic of digital celebrations.

The issue has also interested many religious confessions, bringing the community to live in a much unexpected way some "strong" moments of the religious experience, such as Easter and Christmas for the Catholics, Easter and Christmas for the Orthodox, the Commemoration of the Death of Jesus Christ for the Jehovah's witnesses, and the Ramadan ${ }^{15}$. For Orthodox Jews it was not possible to use online streaming for the liturgies, being them required to meet, but subsidies have been granted for the Pesach celebration, the preparation of the house and the educational material for the children ${ }^{16}$. However, the digital tools, when admitted, have helped the Italian Jewish community keeping united despite the restrictions and the impossibility to meet, particularly on significant occasions, such as the Israel's Independence Day. Technology has allowed the overcoming of local boundaries and the possibility to organize conversations, lessons and in-depth studies, reaching hundreds of worshippers connected simultaneously and a circulation that would have been impossible in a physical meeting. Even Imams, not being able to pronounce their sermon during the Friday prayer, have used the internet to hold their lessons, to be closet o the worshippers, to inform them, renovate their faith and encourage them.

The need to adopt new control measures during the SARS-CoV2 epidemiologic emergency, after having overcome the so called phase 1 of the lockdown, in relation to liturgical celebrations, has determined

${ }^{14}$ Cfr. ITALIAN EPISCOPAL CONFERENCE, Suggerimenti per la celebrazione dei sacramenti in tempo di emergenza Covid-19, 17 march 2020, in www.chiesacattolica.it; APOSTOLIC PENITENTIARY, Note on the Sacrament of Reconciliation in the current pandemic, 19 march 2020, in www.vatican.va.

15 The World Health Organisation has provided guidance to the world's 1.8 billion Muslims on how to deal with the coronavirus during the holy month. But since early March 2020, the Grand Mosque of Rome, the Union of Islamic Communities of Italy (UCOII) and the Italian Islamic Religious Community (COREIS) have extended the guidance of the ulema, theologians and jurists, to all Muslims of East and West. Buddhism, on the other hand, does not provide for streaming recitations.

${ }^{16} \mathrm{Cf}$. Declaration of the Assembly of Rabbis of Italy, Un Sèder insieme ma isolati, 31 march 2020, in www.olir.it. 
a quicker restart, albeit a few disputes, of funeral rituals and, subsequently, with the sharing of some protocols with each of the interested religious confessions, of the celebrations with the participation of the worshippers ${ }^{17}$, in line with the rest of Europe. All the religions, during this not so short period of "eclipse"18 of the principle of pactional bilaterality, have been united by a profound sense of community and by the need to not disperse it, even through the employment of digital communication tools, sharing the challenge of keeping the worshippers united, albeit through "artificial" forms of participation.

17 Cf. L. DECIMO, La "stagione" dei protocolli sanitari tra Stato e confessioni religiose, in www.olir.it, 14 may 2020; G. MACRÌ, Brevi considerazioni in materia di governance delle pratiche di culto tra istanze egualitarie, soluzioni compiacenti e protocolli (quasi) "fotocopia", in Stato, Chiese e pluralismo confessionale, cit., 11, 2020, pp. 68-96; A. TIRA, Normativa emergenziale ed esercizio pubblico del culto. Dai protocolli con le confessioni diversi dalla cattolica alla legge 22 maggio 2020, n. 35, in Giustizia insieme, 8 june 2020; M.L. LO GIACCO, I "protocolli per la ripresa delle celebrazioni delle confessioni diverse dalla cattolica": una nuova stagione nella politica ecclesiastica, in Stato, Chiese e pluralismo confessionale, cit., 12, 2020, in which the author agrees: "Come si vede, il dialogo collettivo e la discussione franca sulle questioni aperte durante la pandemia appaiono un elemento costitutivo della laicità, che dovrebbe essere ulteriormente implementato alla stregua di una vera e propria "buona prassi". A questo riguardo, Sara Domianello ha utilizzato un'immagine molto efficace quando ha paragonato la laicità alla "tecnica di lavorazione che è destinata a contribuire meglio di altre al successo di una 'buona ricetta' piuttosto che al suo fallimento". Nel caso dei protocolli, la metodologia seguita - ossia, la "tecnica di lavorazione", per restare alla metafora appena citata - si è caratterizzata per il coinvolgimento di tutte le religioni interessate, anche quelle che non hanno stipulato un'intesa ex art. 8 Cost. Perciò si è trattato di un processo inclusivo e non escludente, come è peraltro dimostrato dal fatto che i Testimoni di Geova, che pure non hanno partecipato ai lavori e alla sottoscrizione dei protocolli il 15 maggio, hanno qualche giorno dopo aderito proponendo un proprio protocollo» (p. 113). Point 5.3 of the Protocol states: "Si favoriscano le trasmissioni delle celebrazioni in modalità streaming per la fruizione di chi non può partecipare alla celebrazione eucaristica". In successive notes of June, July and August 2020, the Department for Civil Liberties and Immigration of the Ministry of the Interior, in response to questions from the CEI, clarified a number of issues concerning the use of gloves and the distribution of communion, the use of masks for the bride and groom, the possible exceeding of the maximum limit of 200 participants for religious services in agreement with the regional authorities, the reintroduction of the choir and the fact that members of the same family unit are not obliged to separate themselves from the others.

${ }^{18}$ R. SANTORO, G. FUSCO, Diritto canonico e rapporti Stato-Chiesa, cit., p. 49. 


\section{2 - A survey on the exercise of the worship during lockdown}

The survey on the topic of "Religious freedom and faith in times of Covid-19" has placed itself in this framework, and it has been conducted with the aim of analyzing the reaction of the worshippers/citizens to the "new" experience of faith lived through the phase $1 /$ lockdown of the health emergency crisis caused by the outbreak of the Covid-19 virus, with special reference to the restrictions to the religious freedom right and to the celebrations of the Catholic Church broadcasted digitally. The survey has been promoted by the "Giustino Fortunato" university, in cooperation with the Department of Law of the University of Campania "Luigi Vanvitelli" and with the Department of Canon Law of the Pontifical Theological School of Southern Italy, Saint Thomas Aquinas section and the research group was composed by the teachers Paolo Palumbo (Coordinator), Raffaele Santoro, Elvira Martini, Antonio Foderaro, Edoardo Scognamiglio e Salvatore Forte.

The participation to the survey was great, and the survey has been the absolute first to investigate social-legal issues linked to the religious phenomenon in times of lockdown, and it has registered a total of 4.032 people interviewed. The sample was made mostly of women $(70 \%)$, and the most represented status was "married with children" $(54,44 \%)$, followed by "unmarried laic" $(25,89 \%)$; more than $50 \%$ of the people interviewed declared that they have a direct pastoral commitment and place themselves in the 51-70 years old and up age bracket; and they have a college degree or a post college specialization. About $70 \%$ of the participants declared themselves to be intensively practicing Catholics. Such massive participation is to be interpreted as an unmistakable sign of the need, expressed by the People of God, to be involved in the public debate, and it represents the opportunity for a scientific reflection on the consequences of the changes in the way they experience the catholic religion and on the risks regarding the influence of this on the religious freedom and on the undermining of a healthy cooperation between State and Catholic Church. The survey was developed through the placement of tests (fifteen) developed in three specific areas: the area of the relations between State and Church, the sacramental area and the area related to the risk of "viralization" (as Pope Francis has defined it) of the experience of faith, due to the multiplying of celebrations and religious activities broadcasted online. 
The results of the survey ${ }^{19}$ have given an interesting glimpse on the evaluation conducted on the provisions that have limited, during the lockdown, the participation to the worship life.

Most of the participants felt that the provisions were the expression of a rightful cooperation between State and Catholic Church $(33,06 \%)$, while $25,83 \%$ of them thought that they were right and necessary measure that the Government had to adopt, that is, some rightful and understandable limitation of the religious rights as they were inspired to duties of personal and social responsibility $(19,65 \%)$. Of all the consequences of the provisions adopted by the Government, the one that was less understood by the people interviewed was the prohibition to participate to funerals $(49,34 \%)$, followed, albeit by an ample difference, by the intervention, in some cases, of law enforcement in places of worship $(11,82 \%)$. The deprivation of the worship life that was mostly suffered by the people interviewed has been that of the Holy Communion $(32,38 \%)$, followed by the thought of not being able to receive a proper funeral in case of death $(29,16 \%)$ and of not being able to attend Mass in the church $(20,02 \%)$.

There was a lot of confusion on the topic of the access to places of worship, for personal prayers, during Phase 1 . If $37,5 \%$ of the sample deemed it to be rightfully allowed, provided that the distance of one meter be observed and that the place of worship be the closet to home $33,73 \%$ of the sample thought it was always forbidden. A relevant data is the one regarding the fact that during Phase 1, 65,20\% of the sample never went to church for a personal prayer. Not being allowed to participate in religious functions in the church, $48,24 \%$ of the participants to the survey declared that they followed the functions on television or social media channels, or that they incremented personal and family prayer at home $(31,70 \%)$. Comparing the data to those of the period prior to the current health emergency, spiritual life seems to have increased for $24,08 \%$ of the people interviewed or slightly increased for $19,17 \%$ of them (those who have observed a decrease amount to $7,61 \%$ ). With respect to the perception of the emergency period, $53,55 \%$ of the sample thinks that, in this challenge, God has wanted to make people rediscover the beauty of things and the essential values, and that only God can save us during these times of crisis $(31,82 \%)$.

${ }_{19}$ Available at $h$ ttps://issuu.com/profpaolopalumbo/docs/indagine. 
The answers to the question: "Penso che in questo periodo la Chiesa e $i$ sacerdoti debbano [...]": were various. For $27,17 \%$ of the sample, the fact that the clergy has dedicated itself to enliven the means of communication with religious functions is positive, while $12,35 \%$ would have preferred a higher dedication to acts of charity with donations, a practical commitment to finding solutions in order to restore religious functions in the church with the people attending them $(14,70 \%)$ and a higher closeness to the parishioners that were locked in the house or hospitalized $(17,08 \%)$ or to the marginalized and the poor $(15,19 \%)$. The positive data on the technology meant to promote the participation to religious functions (Sufficiently - 30,75\% quite a lot - 30,21\% - very much - $26,22 \%$ ) has been the confirmation of the centrality held by the means of digital broadcasting during Phase1.

The fact that the functions/activities aired on TV or on social media that have favored the communion amongst worshippers and the fact of feeling like a "Church" $(69,35 \%)$ is considered a positive fact, and only $11,71 \%$ of the sample has thought that the sense of community and the concreteness of the religious celebrations has been lost. The digital tools mostly used to participate in religious functions are: TV $(47,28 \%)$, Facebook $(26,96 \%)$ and You Tube $(11,12 \%)$; however, there have been some flaws in the celebrations, that have been observed by the worshippers, particularly, a sense of discomfort and detachment toward the celebration $(14,69 \%)$ and, most of all, the difficulty in participating with the involvement of the body (standing up/sitting down) (21,59\%). The perception of the people interviewed in relation to the future modalities of participation to religious functions once the health emergency crisis is over are quite significant: $74,21 \%$ of them hopes that everything will go back to normal and a direct and community familiarity with the Lord will be restored; for $19,35 \%$ of them, the social media and the digital channels for the broadcasting of religious functions should be used even after the emergency is over, maybe after having better regulated the phenomenon of the celebrations on TV and on online platforms $(5,73 \%)$. In general, it is thought that the "lockdown of faith" has been an experience that, in time, will be useful to the purpose of reinforcing the faith of everyone $(34,62 \%)$ so that many, that did not attend parish communities, will feel the need to participate in the community activities and functions of the parish $(25,27 \%)$, but also to reinforce the allegiance between State and Catholic Church in pursuing social interest $(12,35 \%)$. 
On the other hand, some problematic profiles have been observed by those who think that the worshippers, despite keeping their faith, will experience it from now in a personal and intimate way, no longer feeling the need to participate in sacraments or in community functions $(14,71 \%)$. Only for a very small percentage of the sample will the solutions adopted during lockdown lead to a "loss" in faith $(2,83 \%)$ turning it into a solely "virtual" experience $(1,98 \%)$, in which the way to participate in the liturgical life will be "reestablished". Behind the word "participate", indeed, are two distinct and irreducible, but also indissoluble concepts: "be a part of" and "take part in". Because of the baptism we already are "part of" and we are in it together, since, together, we constitute the Church, but at the same time, each one with its own peculiarities, is called to also "take part in it". In times of lockdown, the worshipper has felt part of the "ecclesiastic us" that has always brought together the People of God, despite the completely new circumstances, through unusual channels and, most of all, with different dynamics compared to the usual ones; an important role, in this frame work, has been that of the social and digital communication means, social networks in particular, which the Church itself has promoted in view of a correct social communication and that are now been questioned by the law as well regarding their contribution to the post Covid liturgical and sacramental life.

\section{3 - Digital Celebrations: is there a legal regulation?}

Due to the persisting restrictions, after one year from the beginning of the pandemic, it is useful to wonder, regarding the specific subject of the exercise of the worship, whether or not it is time to start a serious reflection regarding the theological premises and the regulation of digital celebrations. Since one year ago, the web is imposing itself as a new "liturgical space" 20 and the worship life has been transferred from the liturgical rooms to the virtual ones (rooms/channels) or to social media pages. This has been certainly determined by the pandemic event, but today, in a unquestionably different epidemiologic situation and with the possibility to restore the physical participation in religious functions, the phenomenon does not seem to come to a halt,

20 Cf. L.M. GUZZO, Il web può essere uno spazio liturgico?, in Moralia blog, 8 april 2020. 
and priests and bishops do not seem willing to renounce to this way of broadcasting the evangelic message, which has pinpointed new forms of proclamation ${ }^{21}$ and has made it possible to envisage the creation, in the future, of actual hybrid parish communities ${ }^{22}$. After one year from the restart of the celebrations with the people, we can surely affirm that the recommendation in the Protocol dated May 2020 was disregarded in the part in which it invited to certainly favor the broadcasting of celebrations in streaming, but only for those who were unable to attend the Eucharistic celebration. A large part of catholic worshippers, instead, remained linked to the digital fruition of the celebrations, by now used to virtual forms of worship. It is certainly true that the pandemic has induced a recovery of the traditions and of the forms of personal prayers, it has lead to a return to the medieval custom of assisting to the Eucharist from a distance without actually receiving it, it has inverted the physical reception of the communion with the practice of the spiritual communion in use in the XVIII and XIX centuries, it has incremented the importance of the local Church, making the concept of the proclamation prevail on the sacramental one. However, the general direction to follow in the future has already been dictated by the Pope during a homily in April 2020, in which he clearly stated the value of the community familiarity with the Lord:

“Una familiarità senza comunità, una familiarità senza il Pane, una familiarità staccata senza la Chiesa, senza il popolo, senza i sacramenti è pericolosa. Può diventare una familiarità - diciamo gnostica, una familiarità per me soltanto, dal popolo di Dio. [...]

21 In the Message of his holiness Pope Francis, signed by the Secretary of State Cardinal Pietro Parolin, on the occasion of the $71^{\text {st }}$ National Liturgical Week, 23 august 2021, in www.vatican.va, is reported that in times of pandemic: "The weekly gathering in the "name of the Lord", which from the very beginning has been perceived by Christians as an indispensable reality and indissolubly linked to their identity, was severely undermined during the most acute phase of the spread of the pandemic. But love for the Lord and pastoral creativity motivated pastors and lay faithful to explore other ways to nourish the communion of faith and love with the Lord and with their brothers and sisters, while waiting to be able to return to the fullness of the Eucharistic celebration in peace and safety. It was a difficult and painful wait, illuminated by the mystery of the Lord's Cross and fruitful in many works of care, fraternal love and service to the people who suffered most from the consequences of the health emergency».

22 Cfr. P.A. MURONI, Liturgia nel post pandemia. Quali prospettive per le celebrazioni liturgiche nel "post-vaccino"?, in Urbaniana University Journal, 2, 2021, pp. 165-189; M. BELLI, M. GALLO, Le trasmissioni delle celebrazioni in streaming e in televisione, in Rivista liturgica, 2, 2021, pp. 153-168. 
Anche il Sacramento: oggi ce l'avete, l'Eucaristia, ma la gente che è collegata con noi, soltanto la comunione spirituale. E questa non è la Chiesa: questa è la Chiesa di una situazione difficile, che il Signore permette, ma l'ideale della Chiesa è sempre conil popolo e con i sacramenti. Sempre ... La Chiesa, i sacramenti, il popolo di Dio sono concreti. È vero che in questo momento dobbiamo fare questa familiarità con il Signore in questo modo, ma per uscire dal tunnel, non per rimanerci. E questa è la familiarità degli apostoli: non gnostica, non viralizzata, non egoistica per ognuno di loro, ma una familiarità concreta, nel popolo. La familiarità con il Signore nella vita quotidiana, la familiarità con il Signore nei sacramenti, in mezzo al popolo di Dio"23.

Following this approach, the Congregation for Divine Worship and the Discipline of the Sacraments, in September 2020 has made clear, in a letter addressed to the Presidents of the Episcopal Conferences that:

«Per quanto i mezzi di comunicazione svolgano un apprezzato servizio verso gli ammalati e coloro che sono impossibilitati a recarsi in chiesa, e hanno prestato un grande servizio nella trasmissione della Santa Messa nel tempo nel quale non c'era la possibilità di celebrare comunitariamente, nessuna trasmissione è equiparabile alla partecipazione personale o può sostituirla. Anzi queste trasmissioni, da sole, rischiano di allontanarci da un incontro personale e intimo con il Dio incarnato che si è consegnato a noi non in modo virtuale, ma realmente, dicendo: "Chi mangia la mia carne e beve il mio sangue rimane in me e io in lui" (Gv 6, 56). Questo contatto fisico con il Signore è vitale, indispensabile, insostituibile. Una volta individuati e adottati gli accorgimenti concretamente esperibili per ridurre al minimo il contagio del virus, è necessario che tutti riprendano il loro posto nell'assemblea dei fratelli, riscoprano l'insostituibile preziosità e bellezza della celebrazione, richiamino e attraggano con il

${ }^{23}$ Homily, 17 april 2020, in www.vatican.va. In a message to priests on 13 May 2020, the Campania Bishops' Conference called for limited use of streaming of celebrations to avoid further dispersion of community participation: "ci sta a cuore il senso della comunità reale e non virtuale". More recently, the same Bishops' Conference (2 February 2021) urged the faithful to attend the Sunday Eucharist in presence, overcoming fear and trusting in the security guarantees of the churches. 
contagio dell'entusiasmo i fratelli e le sorelle scoraggiati, impauriti, da troppo tempo assenti o distratti» 24 .

Nevertheless, even for Easter 2021, as for the previous one ${ }^{25}$, the Note of the Congregation for Divine Worship and the Discipline of the Sacraments ${ }^{26}$ suggested to ease and privilege the broadcasting of the celebrations, particularly those held by the bishop, encouraging the worshippers that were unable to attend their Church to follow the diocesan celebrations as a sign of unity, recognizing that "l'uso dei social media ha molto aiutato i pastori ad offrire sostegno e vicinanza alle loro comunità durante la pandemia".

Despite the practice highlights the indisputable data of the centrality assumed by the digital media in the liturgical and sacramental area, such experience remains, in light of the reminded quotes, contradictory. The TV or web live coverage have eased the unity of the community and the overview of the digital Masses without people strikes and makes us wonder: everywhere, with any

${ }^{24}$ CONGREGATION FOR DIVINE WORSHIP AND THE DISCIPLINE OF THE SACRAMENTS, Letter to the Presidents of the Bishops' Conferences on the celebration of the liturgy during and after the covid-19 pandemic, 12 september 2020, in www.vatican.va. The Italian Bishops' Conference expressed the same view: «La messa in tv è spesso vissuta con partecipazione e devo- zione dal malato, dall'anziano, o da chi si trovi comunque nell'impossibilità di recarsi personalmente in chiesa. E proprio a questi ultimi essa può offrire un servizio spiritualmente assai utile. Anzi, è soprattutto a queste categorie di persone che bisognerà pensare nella preparazione di quelle messe, nell'omelia, nelle intenzioni della preghiera universale. È evidente che una Messa alla televisione o alla radio, che in nessun modo sostituisce la partecipazione diretta e personale all'assemblea eucaristica, ha i suoi aspetti positivi: la parola di Dio viene proclamata e commentata "in diretta", e può suscitare la preghiera; il malato e l'anziano possono unirsi spiritualmente alla comunità che in quello stesso momento celebra il rito eucaristico; la preghiera universale può essere condivisa e partecipata. Manca certamente la presenza fisica, ma l'impossibilità di portare un'offerta all'altare non esclude quella di fare della propria vita (malattia, debolezza, memorie, speranze, timori) un'offerta da unire a quella di Cristo» (ITALIAN EPISCOPAL CONFERENCE, Il giorno del Signore, 1984, in www.chiesacattolica.it).

${ }^{25}$ CONGREGATION FOR DIVINE WORSHIP AND THE DISCIPLINE OF THE SACRAMENTS, Decree In time of Covid-19, 25 march 2020, in www.vatican.va.

26 CONGREGATION FOR DIVINE WORSHIP AND THE DISCIPLINE OF THE SACRAMENTS, Note Celebration of Holy Week. Note to Bishops and Episcopal Conferences on the celebration of Holy Week 2021, 17 february 2021, in www.vatican.va. The guidelines for Holy Week 2021 (24 february) of the C.E.I. also call for priority to be given to media coverage of Episcopal celebrations, specifying that recourse to the use of social media, however, should only be made if strictly necessary and truly useful. 
evidence, the impossible has been made possible in order to make sure the weekday and holiday Masses could be guaranteed to the people that, on one hand are not physically there, but on the other hand are very much present with their expectation to find the Eucharistic liturgy, via television or web. The pandemic has allowed people to discover a Catholic Church that is more social, and also small realities have adapted themselves to this situation, bringing the "digital" in churches.

Parishes and Dioceses have rediscovered their social channels, that were often already present, but not active, and some of them have even offered guidelines and video tutorials with some practical advice for the success of live streaming celebrations. Such documents are especially useful because, on the basis of the experience gained during these times, they shed light on some criticalities of the digital celebrations and, consequently, they highlight the need for a regulation, through a "criterion" that can homogeneously discipline the phenomenon at last ${ }^{27}$.

Of course, amongst the criticalities there are issues that are not necessarily technical (framing, audio, equipment, style, technology and platforms) but also regulatory, mostly linked to the "live" streaming and to the right to privacy of the attendees, considered that, with the filming of the celebration where the people are present, the functions are clearly attended by the worshippers. In this respect it is certainly appropriate, for example, that whenever accessing a sacred place, the worshipper be informed that the celebration is going to be broadcasted in live streaming, or that particular attention be given to children that are not accompanied by a parent, and also that the regulations on protection of cultural heritage and work, in the cases in which the entity has at least one employee, be observed. It is certainly appropriate, as the Social Communication Office of the C.E.I. reminds us in a document dated March 202028, to recreate, during broadcasts in live streaming, an "assembly view", but it is necessary that it does meet the requirements of the right to privacy of the participant worshippers, especially on occasion of the streaming of First Holy Communion, Confirmation, Wedding and Funeral celebrations. All the

27 Cf. the guidelines/indications available on the web of the C.E.I. and of the Dioceses of Milan, Turin, Cuneo and of associations specialised in church communication (e.g. WeCa).

28 ITALIAN EPISCOPAL CONFERENCE, Celebrare in diretta $T V$ o streaming, 27 march 2020, in www.chiesacattolica.it. 
guidelines recall the attention on the attitude of the priest, whom must not indulge in useless virtuosities or in the research of consensus.

Finally, many documents refer to the need, or better, the urgency of a specific training on the value and the employment of digital environments ${ }^{29}$, feeling all the inadequacy of the Directorate on social communications dated $2004^{30}$, in which is impossible to find indications regarding these new issues. The in-depth study on the role of digital media in the liturgy and in the worship life is placed in the path of the recent teachings on the social communication tools, where interest, goodwill, and prudential attitude cross each other, as well summarized in La Chiesa e Internet, a document dated 22 February 2002, of the Pontificial Council for Social Communications ${ }^{31}$, circulated at the same time as Etica in Internet ${ }^{32}$, which considers the means of communication as the result of the scientific historical process thanks to which humanity moves forward in the discovery of the resources and of the value enclosed in Creation, convinced of the fact that such means are, as the II Vatican Council had already affirmed in the declaration Inter mirifica33, "marvelous technical inventions"34 that, albeit doing already a lot to satisfy the human needs, may still do more.

It took the Church decades to adapt to the mass communication experience first, and to information technology after, following the widespread of electric technologies in communication, and we can now maybe say we have reached a turning point of the adaptation to the digital experience. Indeed, the employment of the Internet by religious confessions has been quite broad for a while, and many religious groups, in order to widespread the knowledge of their

29 Cfr. F. AMMENDOLA, Dalla tempesta Covid-19 alla quiete. Una pastorale che si pensa "onlife", in Orientamenti pastorali, 6, 2021, pp. 50-58.

30 ITALIAN EPISCOPAL CONFERENCE, Direttorio sulle comunicazioni sociali nella missione della Chiesa, 18 june 2004, in www.chiesacattolica.it.

31 PONTIFICAL COUNCIL FOR SOCIAL COMMUNICATIONS, The Church and Internet, 22 february 2002, in www.vatican.va.

32 PONTIFICAL COUNCIL FOR SOCIAL COMMUNICATIONS, Ethics in Internet, 22 february 2002, in www.vatican.va.

33 SECOND VATICAN ECUMENICAL COUNCIL, Decree Inter mirifica, in AAS, LVI (1964), pp. 145-157.

34 PONTIFICAL COUNCIL FOR SOCIAL COMMUNICATIONS, The Church and Internet, cit. 
doctrine use digital tools, religious apps 35 , up to reach the "edge" experiences of virtual religious communities ${ }^{36}$, animated by robot ministers (Mindar, the first robotic Buddhist priest), the worshippers of which meet only in 2.0 churches (VR Church, the first virtual reality church).

And so we reach the most profound end central issue, which also influences the contribution that the Law can give to this phenomenon and it is the one related to the theological value of digital celebrations. Can the in streaming celebration be compared to the one conducted in the church? In other words, are they interchangeable? Do the worshippers assist to the celebration in streaming or do they participate in it? How to train them to face to face celebrations, albeit mediated by means of communication, that do not exclude the involvement of the body, through those forms that the physical involvement to the celebration requires to express and to live as a conscious, full, active and fructuous participation? What type of community is forming in the virtual space? Can the Internet be a space in which the sacramental grace is spread as it became a means of evangelization?

These questions are more than licit, especially during these times, in which the liturgical space and the essence of the assembly of the worshippers itself are relativized, and become more fluid, open, digital. We can certainly agree that: the liturgy may not overlook the flesh, and there is no sacramental and liturgical celebration that excludes a necessary materiality; the assembly is created in the meeting and in the summons, and the ritual is a complex experience of corporeality ${ }^{37}$, the sacrament event always occurs in the ritual ${ }^{38}$. Although it is desirable that the digital environment does not substitute the

35 Cfr. R. SANTORO, F. GRAVINO, Internet, culture e religioni. Spunti di riflessione per un web interculturale, in Stato, Chiese e pluralismo confessionale, cit., 20, 2020, pp. 99118.

36 H.A. Campbell is one of the leading experts on so-called digital religion. E. Larsen has been studying Cyberfaith for years. Cfr. C. HELLAND, Online Religion as Lived Religion. Methodological Issues in the Study of Religious Participation on the Internet, in Online Heidelberg Journal of Religions on the Internet, 17, 2005, pp. 1-16.

$37 \mathrm{Cf}$. contributions on the subject in the monographic issues of Rivista di Pastorale liturgica, n. 1, 2020, di Orientamenti pastorali, n. 5, 2020 e di Rivista liturgica, n. 1, 2020.

${ }_{38}$ Cfr. R. MAIER, Streaming eucaristici in tempo di epidemia. Una riflessione in seconda battuta, in ww.olir.it, 29 march 2020: "L'apparente perennità del digitale [...] è in aperto contrato con l'unicità dell'evento sacramentale". 
physical one, it is also true that the house of the community assembly has a secondary role, a character of service compared to the assembly itself. The ecclesiastical community is called, nowadays, to fully comprehend the place that the digital reality occupies in our societies and cultures ${ }^{39}$.

We will have to take into account that the people still believe that everything that is "digital" is actually "virtual", but it is suitable and necessary to wonder whether or not the real world really contrasts with the digital environment, since the enculturation of the liturgy and the sacraments in the digital experience is determining itself in a moment in which the mediation of the internet is an integral part of the existence of people ${ }^{40}$. The disquisitions of those who would want to keep the digital contribution out of the worship and liturgicalsacramental life are out of space and time. Continuing to use the digital tools and to stream celebrations is, by now, part of a reforming identity process for the Church itself, and the spiritual and liturgical experience, as well as theology and canon law ${ }^{41}$, must always understand the reach of this digital revolution of faith, finding

${ }^{39}$ Cfr. N. SINTOBIN, Celebrazioni digitali? Una domanda dall'esperienza, in La Civiltà Cattolica, n. 4078, 2020, pp. 396-398.

40 The issues extend beyond the theme of Eucharistic celebrations, for example to the celebration of penance online or the celebration of marriage online. On the subject of penance, Cardinal Piacenza, Major Penitentiary at the Apostolic Penitentiary, in an interview on 5 December last, in his Letter sent to all confessors on the occasion of Christmas 2020, states: "Possiamo affermare la probabile invalidità della assoluzione impartita attraverso tali mezzi. Manca infatti la presenza reale del penitente e non si verifica reale trasmissione delle parole della assoluzione; si tratta sol- tanto di vibrazioni elettriche che riproducono la parola umana", in www.penitenzieria.va. On the subject of marriage, the Italian Court of Cassation's judgment $n^{\circ} 15343$ of 25 July 2016 has caused much discussion. The case concerns two Pakistani nationals who had married in their country of origin, according to Pakistani law, and therefore without the physical presence of the couple, and with the help of Skype, a wellknown Internet communication software. The Ministry of the Interior did not recognise the validity of the marriage in that, according to the reasons given, the physical absence of the couple at the time of the marriage was contrary to Italian public policy, in accordance with Article 65 of Law 218/1995. The Supreme Court, in the aforementioned judgment, emphasises, however, other provisions of the same law, namely, in the present case, Article 28, relating specifically to the form of the marriage, stating that: "Il matrimonio è valido, quanto alla forma, se è considerato tale dalla legge del luogo di celebrazione o dalla legge nazionale di almeno uno dei coniugi al momento della celebrazione o dalla legge dello Stato di comune residenza in tale momento", and emphasising that this case does not in any way violate domestic public order.

${ }^{41}$ Cf. V. PACILLO, La Libertà di culto di fronte all'emergenza Covid-19, cit., p. 32. 
solutions for proper adaptations. The places of the physical encounter change, and so do those with the divine entity ${ }^{42}$.

Pope Francis, in the apostolic exhortation Christus vivit 43 , talking to an audience of young people, shows a lucid knowledge, clarifying that it is no longer about "using" the means of communication, but about living a widely digitalized culture that has profound impacts on the notion of time and space, on the perception of self, of the others and of the world, on the way we communicate, learn, inform ourselves, relate to others ... and to God?

42 Cf. A. FUCCILlO, Diritto, religioni, culture. Il fattore religioso nell'esperienza giuridica, Giappichelli, Turin, 2019, p. 318 ss.

${ }^{43}$ FRANCIS, Post-Synodal Apostolic Exhortation Christus vivit, 25 march 2019, in www.vatican.va, n. 86. In the Messaggio del santo Padre Francesco a firma del Cardinale Segretario di Stato Pietro Parolin in occasione della $71^{a}$ Settimana Liturgica Nazionale, cit., read: "Il Santo Padre auspica che [...], possa individuare e suggerire alcune linee di pastorale liturgica da offrire alle parrocchie, perché la domenica, l'assemblea eucaristica, i ministeri, il rito emergano da quella marginalità verso la quale sembrano inesorabilmente precipitare e recuperino centralità nella fede e nella spiritualità dei credenti". 